\title{
REMEDY TO THE INADEQUATE REPRESENTATION OF GUIDANCE AND COUNSELLING IN THE NATIONAL POLICY ON EDUCATION
}

\author{
EGBOCHUKU, Elizabeth Omotunde PhD \\ Associate Professor \\ and \\ ALIKA, Ijeoma Henrietta PhD \\ Lecturer \\ Department of Educational Psychology \& Curriculum Studies \\ Faculty of Education, \\ University of Benin, Benin City, Nigeria. \\ e-mail: mamandidi@yahoo.co.uk \\ henriettaalika@yahoo.co.uk
}

\begin{abstract}
In Nigeria, the methods of giving personal assistance to others have gradually given place to the advent of professional guidance. Formal Guidance is the professionalised help, which is given to an individual so that he/she could understand him/herself, others and be able to adjust to his/her environment. It involves undergoing professional training in order to systematize and refine the helping method and techniques. The primary aim of guidance and counselling is to "relieve distress and get the individual or group back to functioning normally, comfortably and effectively within the accepted norms of the society" The planners of the National Policy on Education were aware of the growing need for Guidance services in the Secondary Schools hence it's inclusion in the policy document. They were also aware of the problem of young people. They were not, however, well informed about the scope, potentials and objectives of what Guidance and Counselling entails. This article assessed the presentation of the objectives of guidance and counselling in the National Policy on Education. Additionally, remedy for the inadequate representation of the guidance and counselling objectives as presented in the Nation Policy on Education (NPE: 43) were proffered.
\end{abstract}

Key Words: Guidance and Counselling, Policy, Education, Remedy, Nigeria. 


\section{Introduction}

Guidance and Counselling has been an age long affair in Nigeria dating from the time of our ancestors till the present times. However, it was only in 1959 that it became professionalised. Guidance and counselling is an essential tool for effective interpersonal relationship for selfunderstanding as well as equitable adjustment to one's environment. In support of this, Odebunmi (1992) saw it as encompassing the full range of personalized assistance given to the individual seeking to expand his selfunderstanding and his understanding of others. The guidance and counselling profession is one that is unique and of immense importance to mankind (Egbochuku 1999). Although it is practised in a local form in many quarters, yet many people have not come to grasp with what it entails. It is against this background that the formalised guidance and counselling is faced with many hurdles. In an attempt to remedy this situation, Oladele (1987) analysed the policy guiding the 6-3-3-4education system in Nigeria as follows:

- Creating a self-reliant person who in understanding his strength and weaknesses is able to make wise choices and decisions with the help of the counsellor.

- It helps individuals adjust satisfactory to their society and probable personal futures.

- It eases the work of teachers in schools and so on

While supporting the above statement, Egbochuku (1999), suggested three main aims of the guidance programme:

- To help an individual order his/her experiences.

- To help him define his/her goals.

- To help him/her define values.

With the above laudable importance of Guidance and Counselling, individuals will definitely desire to be guided if only they know who to guide them, what is to be guided on, and the location for the assistance. It is in view of this, that this article is written to highlight the potentials of guidance and counselling as a profession. A case on its inadequate representations in the Nation Policy of Education will also be made. Additionally, remedy for the inadequate representation of the guidance and counselling objectives as presented in the Nation Policy on Education (NPE: 43) will be proffered. 


\section{Definition of Guidance}

Guidance is derived from the word guide, which invariably means to "direct on a course, to give instruction and to manage. Guidance is the aid given to a person who realizes that he/she needs assistance in order to make him/herself a useful and worthwhile citizen of the society which he/she lives in. Moreover, Odebunmi (1992) saw guidance as encompassing the full range of personalized assistance given to the individual seeking to expand his/herself understanding and his/her understanding of others. Egbochuku (2008) opined that 'Guidance would enable the individuals to answer such questions as: Who am I? What am I capable of doing? How can I fit into my society? How can I maximally use the opportunities within my environment to achieve my life goals?'

\section{Traditional Guidance}

There seems to be nothing special or new about the service, because from time immemorial, many people, particularly the uninitiated such as parents, teachers, principals, educational administrators, soothsayers, clergy, elders etc. have been rendering this service. Traditional Guidance can also be known as informal type of help. Achebe (1988) confirms this when she said that members of the society such as friends, members of extended family, chiefs, community elders, and members of one's age group have traditionally provided an informal type of help when called upon. Systematic method of helping people has long been in existence in Nigeria, although this has been disrupted by the advent of Western Education and Christianity. Egbochuku (2008) warned in her book 'Guidance and Counselling: A comprehensive text' that Guidance and Counselling as a delivery service should not be misconstrued for the traditional type that is based on the principles of "to guide, to direct on a course, to enlighten, or to assist", which was principally carried out in African setting by heads of families, Priests, and Church Leaders.

\section{Need For Specialisation:}

Formal Guidance is the professionalised help, which is given to an individual so that he/she could understand him/herself, others and be able to adjust to his/her environment. It involves undergoing professional training in order to systematize and refine the helping method and techniques. However, the primary aim of all helpers is to "relieve distress and get the individual or group back to functioning normally, comfortably and effectively within the accepted norms of the society" (Egbochuku, 1999). Specialisation is one of the numerous ways a 
counsellor can advertise him/herself. It then implies that not everybody can be a professional guide (counsellor) as it was in the olden days when virtually everybody was a counsellor. Achebe (1988) referred to these groups of individuals as the uninitiated.

The counsellors need to be specialists in their profession by way of training in a University. It is the long period of training undergone by these helpers that differentiate formal guidance from the informal guidance. This will solidify their theoretical stand and give them the necessary exposure for practical applications of the theories. Mallum (1990), arguing on the need to train personnel in the field of counselling, stressed that specialists should be trained in sufficient numbers and that guidance and counselling courses should be introduced at the undergraduate levels. He cited the University of Ibadan's programme as an example. The training takes a period of four years as an undergraduate, one year for Master programme and from three years for Doctorate in Guidance and Counselling where necessary.

\section{History of Guidance and Counselling in Nigeria}

In Nigeria, the methods of giving personal assistance to others have gradually given place to the advent of professional guidance. People are also having more complicated problems that solicit for professional touch. This is as a result of technological, political, social, economic and educational changes. The first attempt to introduce guidance into the secondary school was in 1947, according to Iwuama (1991), when representatives from the Federal Ministry of Labour were sent to Bendel State (then part of the Western Region) to give talks to form 5 students on careers and subjects choice. He also noted however, that formal guidance started in 1959 at St. Theresa's College Oke-Ado in Ibadan by some Reverend Sisters who, out of sympathy and concern for the product of their school, felt that these secondary school leavers would have problem in seeking for admission, employment and adjusting to the condition of the society. To meet this need, they invited 29 educated people from Ibadan community who were professionals and understood more about the world of work than the Sisters and students. Consequently, fifty-four out of the sixty students benefited from the experts' advice and they were placed in various jobs.

It was this same group of untrained Counsellors that found the Ibadan career council. The Nigeria Career Council, which was formed in 1967 later developed to an extent where they published a journal known as CAREERS. One can safely conclude that the efforts of these groups contributed immensely to the growth and development of guidance and 
counselling in Nigeria. Odebunmi (1992) and Akinboye (1987) believed that the year 1967 was remarkable in the development of guidance and counselling in Nigeria. This is because that was the year the Nigerian Career Council organised its first workshop for career masters/mistresses and principals on vocational courses for teachers of guidance. Akinboye (1987) noted that another workshop was held at the comprehensive high school Aiyetoro where P.O. Rees delivered a paper on the role of the counsellor. Other factors that enhanced its spread were the visit of 16 Nigeria educators to Sweden, France and U.S.A. in 1962. In addition to this, Iwuama (1991) asserts that an inspector of Education was appointed for vocational and educational guidance in 1972.

Testing Development and Research Office (TEDRO) was not left out of this development. It was formed in December 1963 and has been able to develop up to twenty-one internationally standardised aptitudes tests, which were used for job selection and evaluation of academic performance at secondary and commercial levels (Iwuama, 1991). Iwuama further stated that the importance of guidance and counselling was recognised in the late 1970s by the governments. Thus, more emphasis was placed on the guidance and counselling programme in the National Policy on Education of 1977. As a result of the above development in the History of guidance and counselling, many people are now getting aware of the profession in Nigeria. In line with this, the Counselling Association of Nigeria (CAN) was launched on the $11^{\text {th }}$ of November, 1976 with Professor Olu Makinde as its first President. The association published a journal called the "Counsellor", which is still the official journal of the association. The Counselling Association of Nigeria became affiliated to the American Personnel and Guidance Association (APGA) in 1977. The current president is Professor Ibrahim I. Kolo of Ahmadu Bello University Kaduna. He is also the current Provost of Federal College of Education Minna. .

\section{National Policy on Education}

The National Policy on Education was first published in 1977 and revised in 1981, and 1984. This was borne out of an effort to put quality into the Nigerian Education. According to the policy, the new educational system would be 6-3-3-4. That is six years of Primary school, three years of junior secondary, three years of senior secondary and four year of University education.

It further stated that the two-tier of secondary aims are: 
1. Preparing and selecting pupils for the next stage of educational system.

2. Preparing those who will not proceed to the next stage of education for employment and useful living within the society Osokoya (1987).

\section{Guidance and Counselling as Represented in the National Policy on Education (NPE).}

Nigerian Government in recognition of the importance of Guidance and Counselling to her education system included Guidance in the policy document of the National Policy on Education (1981). Paragraph 83 (II) of the policy document contains the following few lines written about Guidance and Counselling:

In view of the apparent ignorance of many young people about career prospects and in view of personality maladjustment among school children, career officers and counsellors will be appointed in Post-Primary institutions. Since qualified personnel in this category are scarce, Government will continue to make provisions for the training of interested teachers in guidance and counselling. Guidance and counselling will also feature in teacher education programmes (: 43)

The above statement shows that the planners of the National Policy on Education were aware of the growing need for Guidance services in the Secondary Schools hence its inclusion in the policy document. They were also aware of the problem of young people but were not however well informed about the scope, potentials and objectives of what Guidance and Counselling entails. I will now make an attempt at analysing the guidance and counselling programme as presented in the NPE and then give suggestions on what it should be.

\section{Analysis of Guidance and Counselling in the NPE:}

Guidance and Counselling enunciated in the policy document contains some vital point that needs to be analysed. The first line of paragraph 83 reveals that 'young people are ignorant of career prospects and that they have personality maladjustment'. Consequently Guidance Counsellors were to be appointed in post primary institutions. It was observed in the 
policy document that Counsellors are scarce and, as a result, teachers will be trained in guidance and counselling. It was intended that guidance and counselling be included in teacher education programme. The above analysis is an indication that Government has good intention to meet the vocational and personal-social needs of school children in Nigeria. However, as Osokoya (1987) and Egbochuku (1999) put it, Guidance and Counselling is more than what could be given during the teaching learning experiences alone. This is because guidance is broad in scope. It consists of educational, vocational and personal-social in scope. It is the all-round development of the school child or of an individual. In his own contribution on the subject, Prentice (1965) claims that guidance programme should incorporate:
1. Counselling
2. Individual Appraisal Service
3. Informational Service
4. Educational Service
5. Personal/Social Service
6. Placement service
7. Follow-up Service
8. Other Services.

However, there are three broad areas/scopes in Guidance and Counselling which incorporate these services; they are Educational, Vocational, and Personal/Social guidance.

Educational Guidance was conspicuously omitted from the policy document despite its immense importance in the total development of the school child. Educational Guidance is an aspect of guidance services. Quoting Isaksen and Mink (1963), Olayinka (1978) claims that educational guidance involved these experiences, which assist each individual to understand himself, accept others and live effectively in his society. It is designed to help each student adjust to his environment, develop the ability to set realistic educational goals for him and improve his total educational opportunities. According to Egbochuku (2008), 'Educational guidance is essential in the counselling service, guiding young people to pursue the right type of education is necessary, while ensuring that the right balance is kept in order to meet the human resource needs of a nation'. She further opined that secondary school, college and university students need valid and usable information that relate to their developmental and experience levels concerning all types of present and 
future educational opportunities and requirements for entrance and problems of student life.

Vocational guidance is another area of Guidance and Counselling. According to Odebunmi (1992), vocational guidance is the assistance offered to an individual in making up career decision, choices, and to effect satisfactory vocational adjustment. The Nigerian Government appreciated this aspect of guidance and counselling hence its inclusion in the policy statement of the national policy on education. However, educational guidance is needed to achieve vocational guidance. This is because vocational Guidance alone is not enough to enable an individual plan, take the right decision and adjust equitably to his environment.

Personal-social guidance was also not a part of the policy plan except for the part that dealt with "Personality Maladjustment among school children". Personal-social guidance is much more than "Personality adjustment" .It is the assistance given to an individual or a student by a professional counsellor in matters that border on interpersonal problem and problem of life adjustment with fellow students, parents, teachers and other members of the society. Thus, it is very vital in facilitating selfunderstanding, understanding of others and having good relationship with others and the community at large. In effect, it is a grievous oversight to have omitted Educational and personal-social Guidance from the policy document. The career prospect included in the policy document as a policy statement on Guidance and Counselling is just a tip on the iceberg. It was inadequate for an encompassing guidance of the school child.

It was also stated that counsellors would be appointed in PostPrimary institutions. This infers that career masters and qualified counsellors will be sent to secondary schools and not to primary schools. This has, of course, limited the guidance services to only secondary schools. Who says that the primary school pupils do not need guidance services? When they make up the population for secondary schools? This statement has an adverse effect on the Guidance and counselling profession. Training of teachers as Counsellors and the inclusion of guidance and counselling in the teacher education programme have helped matters. The trained teacher who has further training in guidance and counselling will be able to aid each child to take an honest look at him/herself, become aware of his/her potentialities and weaknesses, consider alternatives in the light of existing fact and information and make realist decisions. 
Probable Reasons for Inadequate Representation of Guidance and Counselling in the National Policy on Education.

There are very many reasons responsible for the few lines accorded guidance and Counselling in the policy document. Some of them will be highlighted below:

\section{Guidance and Counselling as a Phenomenon:}

Guidance is as old as man. What is really new about it is the technique used in effecting changes in the individual. Gesinde (1991) supporting this assertion opined that the service is quite new and special. This assertion was however made in 1991; the guidance programme has since come a long way. There are new technological methods of information dissemination (e.g. computer, cable network etc). Formal Guidance technique is indeed a new phenomenon in Nigeria as a whole, and as a result, the general populace, as well as the educationists are not too informed about its scope. Consequently, the planners of this laudable policy were not abreast of what constitute professional Guidance. This must have been responsible for viewing career prospect (vocational guidance) as the only aspect of guidance and counselling.

\section{Wrong orientation:}

There is no doubt that the policy planners had wrong orientation of what Guidance and Counselling is all about. Their narrow mindedness about the profession is a viable reason for the few lines on it. Apart from this, Achebe (1988) argued, the little orientation possessed by the general populace was rather very slow in gaining ground. They did not only have wrong orientation but were also ignorant of the services of counselling and the three major domains of guidance and counselling.

\section{The Need for Quality Education:}

Until the advent of the 6-3-3-4 system of education, Nigeria never had a written statement on guidance and counselling although traditional method of counselling existed before then. Thus, the need to put quality into her education and ensure that education responds to the national need and aspiration of the people led to the inclusion of vocational guidance in the 6-3-3-4 educational policy (Oladele, 1987). It is of great interest to know that the major profession that can assist in providing this quality education is guidance and counselling, through guidance is considered of less importance to be given its rightful page in the policy document. This relegation has hampered the growth and development of 
the profession till date. In addition, unless something is done to remedy this problem, guidance and counselling will remain a profession that cannot achieve her goal in its entirety.

\section{Summary, Conclusion, and Recommendations. \\ How to remedy the inadequacy:}

This article provided useful suggestions to the Nigerian government and the planners of educational policy. The suggestions if adhered to, will assist to correct the shallow representation of guidance and counselling in the policy document. Additionally, it will broaden the horizon of Guidance and Counselling in the Nigerian system of education. It will in addition:

- $\quad$ Correct the wrong impression about guidance and counselling.

- Build the right perception and attitude about guidance and counselling in all the minds of education policy planners and the general populace.

The suggestions below are meant to achieve this.

(a) Re-stating of guidance and counselling in the new policy document (i.e. the inadequate representation of guidance and counselling in the 1977 6-3-3-4 educational policy can be corrected by properly and broadly re-stating it in the new policy document of the Universal Basic Education Scheme). The policy statement should involve the three areas of guidance which are education, vocational and personal-social guidance. It should clearly define the aims of guidance and counselling as it affects the primary, secondary and tertiary institutions. Conclusively, Nigerian Government in recognition of the importance of guidance and counselling to the educational system should not only include it in the policy document of the Universal Basic Education but should also re-state it in a broader view.

(b) Training/awareness programmes for all educational planners: The essence of the training programme is to equip the education policy makers with adequate knowledge on the guidance services. This will afford them the opportunity of rightly and adequately representing it in the policy document. Competent and skilled counsellors with, at least, twenty years field experience should be employed as resource persons by the Government to train the educationists as to what guidance and counselling entails. Osokoya (1987) intimated us that there were six discussion committees for the national policy. Out of the six panels, guidance counsellors were erroneously excluded from it. It is however worthy of 
mention that at the last annual meeting of the Counselling Association Of Nigeria (CASSON) held in Ilorin (2008), members were informed by the President in service, Prof Ibrahim Kolo, of the positive actions he plans to take in regards to the improvement of guidance and counselling. .

(c) Counsellors as part of the planning and implementation committee: The mistake done in the past should not be allowed to repeat itself again. Counsellors should not be left out at the implementation level. They should be a part of the policy makers. This is to ensure adequate representation of guidance programme in the policy document.

(d) Training of counsellors. If there is anytime the country needs Counsellors, it is now. The Federal government's plan to train teachers as Counsellors as stated in the education policy document of 1981 should be scraped from the education policy as this will not help matters. The government should put in place a programme to train fresh individuals as Counsellors and not teachers being trained as Counsellors.

(e) Teachers should be trained as Teachers and they should be made to function in that scope because Nigerian schools are still short of professionally trained teachers. They should not be made to encroach into other people's profession such as the Counselling profession. Rather, they should be limited to their teaching profession. Many schools using teachers as Counsellors no longer want to employ qualified Counsellors and this has led to unemployment in the field of counselling.

(f) Teachers are saddled with so much responsibility already. Making them career teachers in addition to their job make them ineffective in both areas at the end of the day. According to Osokoyo (1989) the guidance and Counselling unit of the Federal Ministry of Education has been involved in the training of school career masters. They have done well in putting this in place. This however is not enough. They should strive to get trained Counsellors as this will go a long way to correct some of the mishaps in our secondary schools.

In Conclusion, therefore, the Counselling Association of Nigeria as a body should address this issue once and for all with the education policy makers as to what the Guidance and Counselling profession is all about in terms of its aims, potentials, professional ethics and scope. 


\section{References}

Achebe, C. C. (1988). Theories of Individual Counselling: Relevance to the Nigerian Situation. Five colleges Black Studies Press Amherst, Massachusetts.

Akinboye, J. O. (1987). Guidance and Counselling Strategies for Handling Adolescents and Youth Problems, Ibadan University Press Limited.

Egbochuku, E. O. (2008). Guidance and counselling: A comprehensive text. UNIBEN Press

Egbochuku, E. O. (1999). Guidance and Counselling: A Tool for Improving Teaching and Learning in Nigerian Secondary Schools. Association for Promoting Quality Education in Nigeria_(APQEN). (10): 188-197.

Federal Republic of Nigeria (1981). National Policy on Education Lagos Government Printer: 43

Iwuana, B.C. (1991). Foundations of Guidance and Counselling Supreme_Ideal Publishers Int. Limited, Benin City.

Odebunmi,A (1992).Understanding Guidance and Counselling. Printed by Gbemi Sopipo Press LTD Abeokuta

Oladede, J.O. (1987). Guidance and Counselling. Focus on the 6-3-3-4 Educational System. John-Lad Enterprises (Publisher), Somolu, Lagos.

Olayinka, M.W. (1978). Definition of Guidance and Counselling, and their Roles in Education. A paper presented at Cafrad's Career Guidance Trainers Workshop Lagos. P. 1

Osokoya, I. O. (1987). 6-3-3-4 Education in Nigeria, History, Strategies Issues and problems. Bisinaike Educational Publishers and Printers. Lagos.

Prentice, H. (1965). School Executives, Guide, Board of 46 contributors, Eaglewood Cliffs, new Jersey. 